Стаднік Анатолій Володимирович

Національна академія Національної гвардії України

\title{
ПСИХОЛОГІЧНА ГОТОВНІСТЬ МАЙБУТНІХ ОФЩЕРІВ НАЦІОНАЛЬНОЇ ГВАРДІЇ УКРАЇНИ ДО СЛУЖБОВО-БОЙОВОї ДІЯЛЬНОСТІ
}

Розглянуто сутність психологічної готовності майбутніх офіџерів до службово-бойової діяльності. Визначені іï структурні складові з метою проведення подальшої психологічної підготовки

Ключові слова: психологічна готовність, психологічна підготовка, майбутні офіџери НГУ.

Аналіз публікацій (виділення невирішених проблем). Національна гвардія України $€$ військовим формуванням 3 правоохоронними функціями, що входить до системи Міністерства внутрішніх справ України і призначено для виконання завдань із захисту та охорони життя, прав, свобод і законних інтересів громадян, суспільства і держави від злочинних та інших протиправних посягань, охорони громадського порядку та забезпечення громадської безпеки, а також у взаємодії з правоохоронними органами - із забезпечення державної безпеки i захисту державного кордону, припинення терористичної діяльності, діяльності незаконних воєнізованих або збройних формувань (груп), терористичних організацій, організованих груп та злочинних організацій.

Проведення антитерористичної операції (АТО) на Донбасі вимагає удосконалення системи підготовки курсантів до службовобойової діяльності де психологічна складова грає одну з ключових ролей. Наявність реальних загроз в умовах проведення АТО обумовлює необхідність якісної підготовки та формування у майбутніх офіцерів психологічної готовності до дій. Тому питання дослідження формування психологічної готовності майбутніх офіцерів до службово-бойової діяльності на сьогодні є актуальними.

Аналіз останніх досліджень i публікацій. Сучасні психологічні дослідження накопили значний теоретичний та практичний матеріал про проблему готовності людини до професійної діяльності. Науковці мають досить багато розбіжностей щодо трактування поняття «психологічної готовності», мають різні погляди на іiї структуру, основні параметри, тривалість і стійкість проявів [4]. 
Мета - визначити сутність та структуру психологічної готовності майбутніх офіцерів Національної гвардії України до службово-бойової діяльності.

Виклад основного матеріалу. У психологічному словнику готовність до дії визначено як «стан мобілізації всіх психофізіологічних систем людини, що забезпечує ефективне виконання певних дій». Конкретний стан готовності до дії визначається поєднанням факторів, що характеризують різні рівні готовності: фізичну підготовленість. необхідну нейродинамічну забезпеченість дії, психологічні умови. Залежно від умов виконання, провідною може бути одна 3 цих сторін готовності до діяльності [7].

Різні автори по-різному визначають і співвідносять категорії «психологічна готовність», «змобілізованість», «боєздатність», «налаштованість», «стійкість» і т.д. Зорема, С. Л. Рубінштейн вказував, що «початком будь-якої вольової дії є стан, що виникає в результаті попередньої тривалої і складної внутрішньої роботи. Цей стан можна було б охарактеризувати як стан готовності, внутрішньої мобілізованості. Іноді перехід до дії відбувається 3 внутрішньою необхідністю природного процесу, і дія стає схожою на бурхливий потік зі сніжних вершин; іноді ж, незважаючи на те, що певне рішення вже прийнято, потрібно ще зібратися, щоб від рішення перейти до виконання» [1]. Таким чином підкреслюється, що готовність - це стан, що характеризується динамічною концентрацією внутрішніх сил людини та дозволяє ӥй доцільно регулювати свою діяльність. У той же час указується, що реалізація в діях може відбуватися по-різному. В одних випадках потрібним $\epsilon$ вольове зусилля, а в інших дія $\epsilon$ природною відповіддю психіки людини на зовнішні подразники.

Аналізуючи напрацювання вчених щодо проблеми формування психологічної готовності майбутніх офіцерів до військової діяльності, можна виділити два основні теоретичні підходи: функціональний та особистісний.

Функціональний підхід формування психологічної готовності військовослужбовців до професійної діяльності розглядає іiі, як певний стан психічних функцій, який забезпечує високий рівень досягнень при виконанні службово-бойових завдань. Так, автори підручника «Психологія професійної діяльності офіцера» [6] стверджують: що «психологічна готовність - це націленість, активність, налаштованість, мобілізованість психіки воїна на подолання якихось труднощів бойових дій, а також саме їхнє подолання». Військовий психолог В. Ягупов визначає стан психологічної готовності як «спрямованість і змобілізованість психіки воїнів на подолання майбутніх бойових труднощів, яка забезпечує результативність і якість виконання 
бойових завдань, адекватно їх складності, значущості та важливості» [8].

Особистісний підхід формування психологічної готовності військовослужбовців до професійної діяльності розглядає іiі, як тривалий психічний стан, стійкий комплекс особистісних якостей, необхідних для успішної діяльності при виконанні службово-бойових завдань. Так, Г. Гребенюк трактує психологічну готовність курсантів і слухачів вищого військового закладу до професійної діяльності як систему професійно-важливих якостей, властивостей особистості, необхідних та достатніх для ефективної професійної діяльності [3].

У своїх дослідженнях М. І. Дьяченко та Л. А. Кандибович описують такі структурні компоненти психологічної готовності, як: усвідомлення своїх потреб вимог суспільства, колективу або поставленому завданню; усвідомлення цілей, вирішення яких задовольнить потреби виконання завдання; осмислення і оцінка умов діяльності; актуалізація досвіду, який пов'язаний з рішенням [4].

М. Багашов та М. Лук'янова [1] рахують, що компоненти психологічної готовності до професійної діяльності повинні включати:

- пізнавальну активність: мотиваційну та операційну;

- інтелектуальну активність;

- прагнення до реалізації та прояву себе, самоактуалізації незалежно від середовища, в якому знаходиться людина.

А. М. Столяренко в структурі психологічної готовності виділяє мотиваційні (спонукають до дій наслідкам), пізнавальні (дозволяють розуміти навколишнє), емоційні (пов'язані з переживаннями ставлення до цих подій), вольові (забезпечують подолання труднощів) i психомоторні (беруть участь у провадженні рухів) психічні явища [7].

На думку О. Колесніченка [5] психологічна готовність працівників МНС України до професійної діяльності в екстремальних умовах містить у собі такі основні компоненти: мотиваційний, типологічний, вольовий, когнітивний і регуляторний.

Підводячи підсумки теоретичного аналізу структурних компонентів психологічної готовності ми рахуємо, що психологічна готовність військовослужбовця до виконання поставлених завдань - це своєрідний фундамент його активних дій в майбутньому бою. Знання військовослужбовцем своїх психологічних особливостей дозволяє йому керувати власною психікою i ефективно діяти в складних бойових ситуаціях.

Структура психологічної готовності майбутніх офіцерів Національної гвардії України до службово-бойової діяльності містить мотиваційний, пізнавальний, емоційний, вольовий i діяльнісний компоненти. Де мотиваційний компонент - це є загальний настрій на успішне виконання службово-бойової діяльності, пізнавальний 


\section{Збірник наукових статей}

компонент - це когнітивний аналіз ситуації i пошук способів вирішення службово-бойових завдань, емоційний компонент загальне ставлення до виконання службово-бойових завдань; вольовий - здатність управлять собою і максимальну мобілізацію власних сил для виконання службово-бойових завдань та діяльнісний - уміння i навички, необхідні для ефективного виконання службово-бойових завдань.

Психологічна готовність військовослужбовця до виконання поставлених завдань досягається в процесі цілеспрямованої психологічної підготовки, яка здійснюється в ході навчання i виховання у вашому військовому навчальному закладі.

Висновки. Отже, психологічна готовність військовослужбовця до виконання поставлених завдань - це основа його активних дій в майбутньому бою, що містить мотиваційний, пізнавальний, емоційний, вольовий i діяльнісний компоненти та досягається в процесі цілеспрямованої психологічної підготовки, яка здійснюється в ході навчання і виховання у вашому військовому навчальному закладі.

\section{Література}

1. Багашов M. M. Специфика подготовки психологов к профессиональной деятельности в различных социальнопроизводственных средах / М. М. Багашов, М. И. Лукьянова // Психофизиологическая наука и образование. - М. : Наука, 1998. - № 2. - С. $10-14$.

2. Бродовська В. Й. Тлумачний словник психологічних термінів в українській мові : словарь / В. Й. Бродовська, І. П. Патрик, В. Я. Яблонко. - Миколаїв : Видавництво ПСІ КСУ, 2003. - 216 с.

3. Гребенюк Г. С. Мотиваційна готовність курсантів і слухачів вищого військового учбового закладу до професійної діяльності (на прикладі спеціалістів пожежної безпеки МВС України) : автореф. дис. на здобуття наук. ступеня канд. психол. наук : спец. 20.02.02 «Військова педагогіка та психологія» / Г. С.Гребенюк. - К. : Київський гум. ін-т., 1997. - 17 с.

4. Дьяченко М. И. Психологический словарь-справочник М. И. Дьяченко, Л. А. Кандыбович. - М. : Харвест, 2004. - 576 с.

5. Колесніченко О. С. Психологічна готовність працівників МНС України до професійної діяльності в екстремальних умовах : автореф. дис... канд. психол. наук : 19.00.09 / О. С. Колесніченко. - Х., 2011. -19 c.

6. Психологія професійної діяльності офіцера: Підручник. Хмельницький : Видавництво Академї ПВУ, 1999. - 488 с.

7. Столяренко О. Б. Психологія особистості. Навч. посіб. / О. Б. Столяренко. - К. : Центр учбової літератури, 2012. - 280 с. 
8. Ягупов В. В. Військова психологія: підручник / В. В. Ягупов. - К. : Тандем, 2004. - 656 с.

Анатолий Стадник. Психологическая готовность будущих офицеров Национальной гвардии Украины в служебно-боевой деятельности.

Рассмотрень сущность психологической готовности будущих офицеров $к$ служебно-боевой деятельности. Определены ее структурные составляющие с целью проведения дальнейшей психологической підготовки.

Ключевые слова: психологическая готовность, психологическая подготовка, будущие офищеры НГУ.

Anatoliy Stadnik. The psychological readiness of future officers of the National Guard of Ukraine to military service.

The essence of psychological readiness of future officers for militarycombat activity is considered. Its structural components are determined in order to carry out further psychological training.

Keywords: psychological readiness, psychological preparation, future officers of NMU.

Стаття надійшла до редакційної колегії 31.10.2017

\section{Інформація про автора:}

Стаднік Анатолій Володимирович - кандидат медичних наук, доцент, Національна академія Національної гвардії України. 